\title{
Natural Resources Revenue, Fiscal Policy and Economic Growth: Panel Data Analysis for Sub-Saharan Africa Countries
}

\author{
Asst. Prof. Dr. Savaş Çevik (Selçuk University, Turkey) \\ Prof. Dr. Ahmet Ay (Selçuk University, Turkey) \\ Ph.D. Candidate Mahamane Moutari Abdou Baoua (Selçuk University, Turkey)
}

\begin{abstract}
The main purpose of this study is to examine the relationship between natural resources revenue, fiscal policy and economic growth for 35 selected Sub-Saharan African countries. The panel data covering the periods of 19862014 was analyzed by using the fixed/random effect model estimation and the panel causality test. We also performed the panel unit root test in order to insure that our variables are stationary. The empirical results indicate that there is insignificant negative effect of natural resources revenue and bad fiscal policy on the economic growth. However, there is significant positive effect of capital formation on economic growth. We also found a bidirectional causality relationship between Natural resources rents and economic growth. There is also unidirectional causality link from government final consumption expenditure to Natural resources revenue and from Natural resources revenue to capital formation. These empirical results mean that Sub-Saharan African countries apply bad fiscal policy to improve the natural resource sector which does not efficiently contribute to the economic growth. This study suggests that countries of Sub-Saharan Africa must apply improved fiscal policy in order to add tax revenue to their total revenue; and they must also use the natural resources revenue in order to invest in other sectors such as education, manufacturing and agriculture.
\end{abstract}

\section{Introduction}

Among the many studies on the effect of natural resource revenues on growth there are those (such as Sachs \& Warner, 1995) who have indicated that these incomes have not been used for the economic development of developing countries. While other researches (such as Gylfason \& Zoega, 2002 and Karimu et al., 2016) have found that natural resource revenues contribute to the economic growth of developing countries. However, all these researches did not investigate whether the natural resources rents have some impact on fiscal policy and capital formation of countries rich in natural resources. Most of these countries are from Africa (specially the SubSaharan Africa) and belong to the list of poorest countries in the world.

Rich in oil and natural resources, the African continent holds a strategic position and remains a key territory on the global map. It is the world's fastest-growing region for FDI, and it has approximately $30 \%$ of the earth's mineral resources. Africa is home to more than 54 different nations, and around 2,100 languages. Sub-Saharan Africa has around six of the world's 10 fastest-growing economies. North Africa has a vast oil and natural gas deposits; and the Sahara holds the most strategic nuclear ore; and resources such as coltan, gold, and copper, among many others, are abundant on the continent. Africa's natural resources accounted for $77 \%$ of total exports and $42 \%$ of government revenues in 2012. Natural resources rents (total natural resources rents are the sum of oil rents, natural gas rents, coal rents, mineral rents, and forest rents) represent a significant development opportunity for African people. However, the lack of leadership and the income inequality in Africa (especially in Sub-Saharan Africa), prevents the development of this area (Al Jazeera, 2016).

In Figure-1, we provide the Map of Sub-Saharan Africa by natural resources, and according to this map, $85 \%$ of Sub-Saharan Africa is rich in natural resources. In Africa the only non-resources-rich countries are Senegal, Togo, Benin which support their needs with tourism and agriculture revenue, Ethiopia which uses infrastructures investments to grow, Djibouti, Eritrea and Somali which is one of the most troubled place in the world. The new resources-rich countries are Ivory Coast, Sudan, Mauritania, Liberia, Burkina Faso, Mozambique and Madagascar. The biggest economy of Africa, Nigeria which is the biggest oil exporter in Africa, started to create another revenue sources in order to decrease the dependency on oil revenue. While Ghana is growing because of resources revenue, Kenya, Malawi and Uganda are emerging resources-rich countries.

In this context, the aim of this study is to investigate the effect of Natural resources rents and the fiscal policy to the economic growth by using the panel data of 35 selected countries of Sub-Saharan Africa covering the 19862014 periods. To do so, our study is structured as follow. The second section provides the literature review of studies relating our subject. In section three (3), we provide the data and methodology specification while the empirical results are giving in section four (4). Then we conclude in section five (5). 


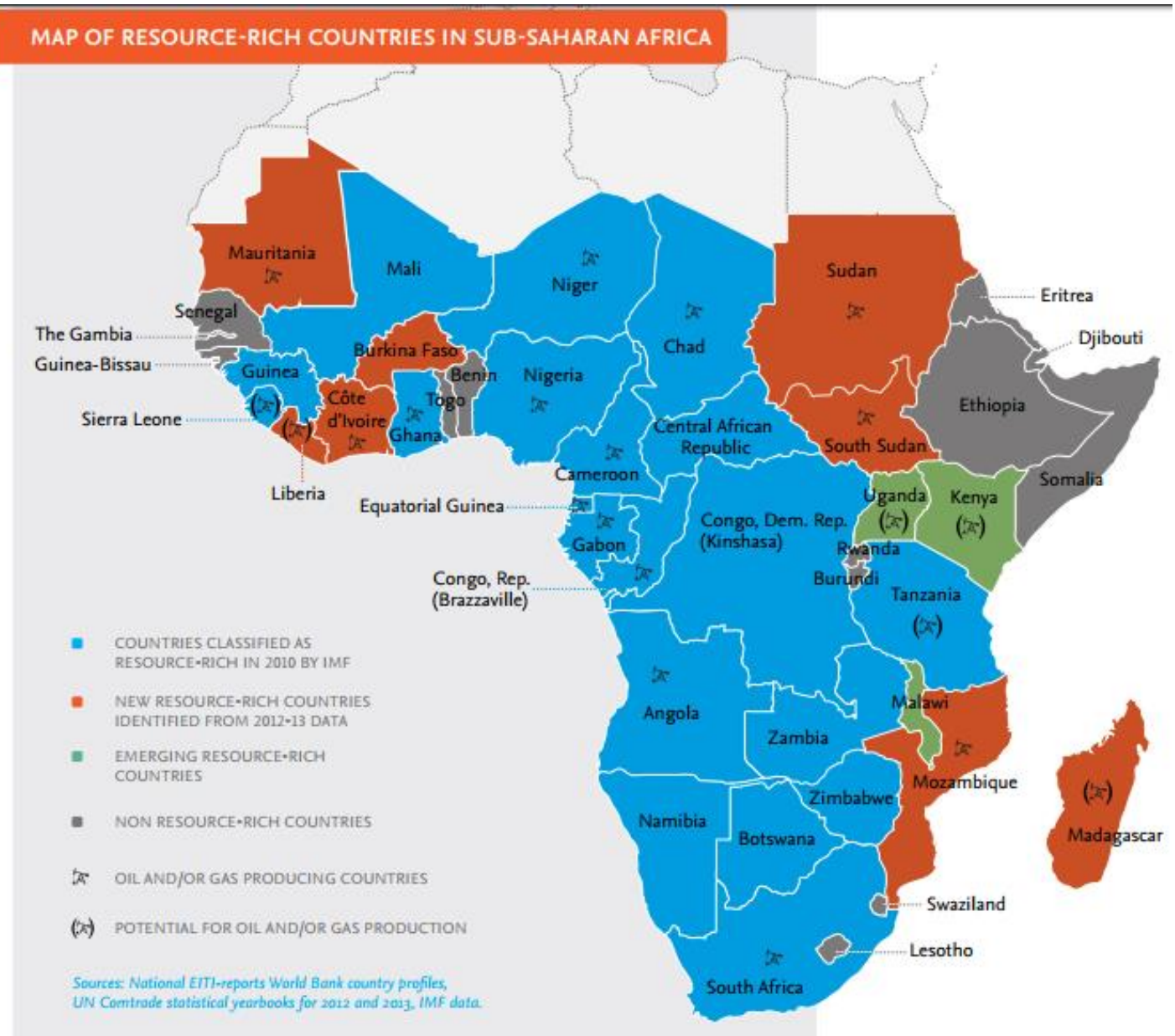

Figure 1. Map of Resource-Rich Countries in Sub-Saharan Africa Source: Thorborg \& Blomqvist (2015)

\section{Literature Review}

Since the aim of our study is to investigate the effect of natural resources abundance, to the fiscal policy and economic growth, we consult some study related to this subject. In one hand some studies emphasize that natural resources revenue hurt the economy throughout fiscal policy. In this context, Sachs \& Warner (1995) indicated that there is negative relationship between natural resources revenue and economic growth. However, in other hands, some studies found a positive effect of natural resources abundance on economic growth. For instance, Gylfason \& Zoega (2002) and Karimu et al. (2016) found a positive effect of natural resources rents on public investment which leads to economic growth. In order to provide the literature review about natural resources abundance, the fiscal policy and economic growth we create a table that shows theses empirical studies by date \& authors, variables, methods and findings. The table is sorted by year of publication. 


\begin{tabular}{|c|c|c|c|}
\hline Authors & Variables used - Countries/years & Methodology & Findings (evidences) \\
\hline $\begin{array}{l}\text { (Sachs \& } \\
\text { Warner, } \\
\text { 1995) }\end{array}$ & $\begin{array}{l}\text { Ratio of primary products export to GDP, Initial } \\
\text { Income, 1971-1989, developing countries }\end{array}$ & $\begin{array}{l}\text { Regression } \\
\text { equation } \\
\text { estimation }\end{array}$ & $\begin{array}{l}\text { There is negative relationship } \\
\text { between natural resources } \\
\text { revenue and economic growth. }\end{array}$ \\
\hline $\begin{array}{l}\text { (Gylfason \& } \\
\text { Zoega, } \\
\text { 2002) }\end{array}$ & $\begin{array}{l}\text { Initial per capita income, share of natural capital in } \\
\text { national wealth, share of gross domestic investment } \\
\text { in GDP, secondary-school enrolment rate, Gini, for } \\
1965-1998 \text { and developing countries. }\end{array}$ & $\begin{array}{l}\text { OLS model, } \\
\text { Estimation } \\
\text { method }\end{array}$ & $\begin{array}{l}\text { natural resources and education - } \\
\text { can help account for the inverse } \\
\text { relationship between inequality } \\
\text { and growth. }\end{array}$ \\
\hline $\begin{array}{l}\text { (Asiedu, } \\
\text { 2006) }\end{array}$ & $\begin{array}{l}\text { Share of Fuel and Minerals in Exports, } \\
\text { development, human capital and openness to FDI, } \\
\text { GDP ... } 22 \text { sub-Saharan African countries over the } \\
\text { period } 1984-2000 \text {. }\end{array}$ & $\begin{array}{l}\text { Panel data } \\
\text { study fixed } \\
\text { and random } \\
\text { effects model }\end{array}$ & $\begin{array}{l}\text { large local markets, natural } \\
\text { resource endowments, good } \\
\text { infrastructure, low inflation, an } \\
\text { efficient legal system and a good } \\
\text { investment framework promote } \\
\text { FDI. }\end{array}$ \\
\hline $\begin{array}{l}\text { (Hayat, } \\
2014)\end{array}$ & $\begin{array}{l}\text { real per capital GDP } \\
\text { growth and the ratio of net FDI inflow to GDP, } \\
\text { average years of secondary school attainment, ratio } \\
\text { of trade volume, ratio of } \\
\text { gross domestic private investment, government } \\
\text { spending, Natural resources exports as a share of } \\
\text { total export } 1993 \text { to } 2012,106 \text { developing countries }\end{array}$ & $\begin{array}{l}\text { panel data } \\
\text { study fixed } \\
\text { and random } \\
\text { effects model }\end{array}$ & $\begin{array}{l}\text { The presence of natural resources } \\
\text { slows the growth induced by FDI. }\end{array}$ \\
\hline $\begin{array}{l}\text { (Karimu, } \\
\text { Adu, } \\
\text { Marbuah, } \\
\text { Mensah, \& } \\
\text { Amuakwa- } \\
\text { Mensah, } \\
\text { 2016) }\end{array}$ & $\begin{array}{l}\text { gross fixed capital formation, stock of public } \\
\text { capital, natural resource rents; 1990-2013, 39 Sub- } \\
\text { Saharan African countries }\end{array}$ & $\begin{array}{l}\text { Generalized } \\
\text { method of } \\
\text { moment } \\
\text { (GMM) } \\
\text { estimator }\end{array}$ & $\begin{array}{l}\text { There's positive effect of public } \\
\text { investment on economic growth } \\
\text { and Resource rents significantly } \\
\text { increase public investment in } \\
\text { Sub-Saharan Africa. }\end{array}$ \\
\hline $\begin{array}{l}\text { (Badeeb, } \\
\text { Lean, \& } \\
\text { Clark, 2016) }\end{array}$ & $\begin{array}{l}\text { Per capita household expenditure, The vector of } \\
\text { explanatory variables and The term error }\end{array}$ & $\begin{array}{l}\text { Simple linear } \\
\text { function }\end{array}$ & $\begin{array}{l}\text { There is a negative effect of } \\
\text { natural resource dependence on } \\
\text { economic growth. }\end{array}$ \\
\hline $\begin{array}{l}\text { (Awolusi, } \\
2016)\end{array}$ & $\begin{array}{l}\text { The real growth of mining, share of mineral exports } \\
\text { to total exports, real growth of agriculture, real } \\
\text { growth of manufacturing, human capital } \\
\text { development, population growth, mineral resource } \\
\text { endowments, infrastructural development, real } \\
\text { growth in services, trade openness and growth in } \\
\text { foreign direct investment, for } 14 \text { countries in the } \\
\text { Southern African Development Community } \\
\text { (SADC) in 1990-2014 }\end{array}$ & $\begin{array}{l}\text { Ordinary } \\
\text { Least Squares } \\
\text { (OLS) and } \\
\text { Generalized } \\
\text { Method of } \\
\text { Moments } \\
\text { (GMM) }\end{array}$ & $\begin{array}{l}\text { Real growth in services, real } \\
\text { growth of manufacturing, real } \\
\text { growth of agriculture, real growth } \\
\text { of mining, human capital } \\
\text { development, infrastructural } \\
\text { development, trade openness, and } \\
\text { growth in foreign direct } \\
\text { investment are important } \\
\text { determinants of economic growth. }\end{array}$ \\
\hline $\begin{array}{l}\text { (Ugwuanyi } \\
\text { \& Ugwunta, } \\
\text { 2017) }\end{array}$ & $\begin{array}{l}\text { Unproductive Expenditure, government productive } \\
\text { expenditure, Distortionary taxes, Budget Surplus, } \\
\text { 1990-2012, Sub-Saharan Africa }\end{array}$ & $\begin{array}{l}\text { panel least } \\
\text { squares, } \\
\text { fixed-effect } \\
\text { assumptions }\end{array}$ & $\begin{array}{l}\text { Budget balances have significant } \\
\text { effects on economic growth. }\end{array}$ \\
\hline $\begin{array}{l}\text { (Janda \& } \\
\text { Quarshie, } \\
\text { 2017) }\end{array}$ & $\begin{array}{l}\text { GDP growth, manufacturing growth, population } \\
\text { growth, external debt, ores and metal exports, fuel } \\
\text { export, Life expectancy and Tax Revenue, } 1980 \text { - } \\
2010 \text { on } 34 \text { Sub-Saharan African countries }\end{array}$ & $\begin{array}{l}\text { A panel data } \\
\text { regression } \\
\text { model }\end{array}$ & $\begin{array}{l}\text { Natural resources have negative } \\
\text { impact on economic growth }\end{array}$ \\
\hline
\end{tabular}

Table 1. The Literature Review about Relationship between Natural Resources Abundance, the Fiscal Policy and Economic Growth

\section{Data and Methodology}

\subsection{Data Specifications}

As we specified above, the aim of our study is to investigate the link between natural resources rents, fiscal policy and economic growth for 35 selected Sub-Saharan African countries, we used GDP per capita as dependent variable, Total natural resources rents ( $\%$ of GDP), General government final consumption expenditure (\% of GDP) and Gross Fixed Capital Formation percentage of GDP as independent variables. The data of 35 selected African countries covering the 1986-2014 periods was bulk from World Development Indicator database.

\subsection{Methodology}

Before estimating the model, we will perform the Panel unit root, which consists to test whether the variables are stationary, or not by examining whether there are restrictions on the autoregressive process across crosssections or series. The AR(1) process for panel data is as follow:

$$
y_{i t}=\rho_{i} y_{i t-1}+X_{i t} \delta_{i}+\epsilon_{i t}
$$


where $i=1,2, \ldots . \mathrm{N}$ represents the cross-section units or series, that are observed over periods $t=1,2, \ldots \mathrm{Ti}, \mathrm{X}_{\mathrm{it}}$ the exogenous variables in the model, including any fixed effects or individual trends, $\rho_{\mathrm{i}}$ the autoregressive coefficients, and $\epsilon_{i t}$ the errors. Recent research indicates that panel unit root test has more power than individual unit root test; that is why we will use three tests to investigate the stationarity of our variables. In this study, we used Levin, Lin and Chu (2002) - LLC which assumes that there is a common unit root process so that $\rho_{i}$ is identical across cross-sections and Fisher-type tests using ADF and PP tests used by combine the p-values from individual unit root tests (Maddala and Wu (1999) and Choi (2001)).

This study used the panel data regression (random/fixed effects) model and Panel Causality test to investigate the link between natural resources rents, fiscal policy and economic growth. The following equation (which refers to the $\mathrm{Y}=\mathrm{C}+\mathrm{I}+\mathrm{G}$ growth model) was estimated for each country using Panel Least Squares model.

$$
\Delta G D P_{i t}=\alpha_{0}+\beta_{1} T N R R_{i t}+\beta_{2} G G F C_{i t}+\beta_{3} G F C F_{i t}
$$

Where,

GDP $=$ GDP per capita as a proxy of economic performance.

TNRR $=$ Total natural resources rents ( $\%$ of GDP) as a proxy of Natural resources revenue

GGFC $=$ General government final consumption expenditure ( $\%$ of GDP) as a proxy of Fiscal Policy

GFCF $=$ Gross fixed capital formation ( $\%$ of GDP) as a proxy of capital formation

$\beta_{1}, \beta_{3}$ and $\beta_{2} \neq 0$

The Panel Least Squares model has three types of regressions: Pooled regression, fixed effects regression and Random regression. The first one does not distinguish between the cross-section countries. That is meaning denying the heterogeneity and individuality that may exist between the pooled countries and it is assumed that the coefficients are the same for all individuals. The fixed effects or LSDV model allows heterogeneity and individuality among countries by allowing having their own intercept value. Fixed effect means that although the intercept may differ across countries, intercept does not vary over time. However, in the random model the countries have a common mean value for intercept. In order to decide which model is appropriate, Hausman test must be used.

We also performed the Pairwise Panel Causality test adopted by Dumitrescu \& Hurlin (2012), which makes an extreme opposite assumption by allowing all the coefficients to be different across cross-sections. This test which is one of the two Panel Causality test offered by EViews, is calculated by running standard Granger Causality regressions for each cross-section individually. The next step is to take the average of the test statistics, which are termed the Wbar statistic. They show that the standardized version of this statistic, appropriately weighted in unbalanced panels, follows a standard normal distribution. This is termed the Zbar statistic (EViews, 2017).

\section{Emprical Results}

\subsection{Unit Root Test Results}

Our data must be stationary for us to perform the Panel Analysis. The results of Levin, Lin and Chu, Augmented Dickey-Fuller (ADF) and Fisher-PP tests were performed in level and First difference and given in Table-2.

\begin{tabular}{|c|c|c|c|c|c|c|c|c|c|c|}
\hline \multicolumn{11}{|c|}{ Level } \\
\hline Tests & \multicolumn{3}{|c|}{ LLC } & \multicolumn{3}{|c|}{ ADF } & \multicolumn{3}{|c|}{ PP } & \multirow{2}{*}{ Decision } \\
\hline Variables & Intercept & $\begin{array}{l}\text { Trend \& } \\
\text { intercept }\end{array}$ & None & Intercept & $\begin{array}{l}\text { Trend \& } \\
\text { intercept }\end{array}$ & None & Intercept & $\begin{array}{l}\text { Trend \& } \\
\text { intercept }\end{array}$ & None & \\
\hline GDP & 1.00 & 0.27 & 1.00 & 0.66 & 0.35 & 1.00 & 0.97 & 0.96 & 0.99 & Non-stationary \\
\hline GFCF & 0.10 & 0.004 & 0.88 & 0.01 & 0.004 & 0.98 & 0.003 & 0.02 & 0.99 & Non-stationary \\
\hline GGFC & 0.00 & 0.00 & 0.064 & 0.00 & 0.00 & 0.81 & 0.00 & 0.006 & 0.50 & Non-stationary \\
\hline TNRR & 0.00 & 0.00 & 0.12 & 0.00 & 0.001 & 0.75 & 0.00 & 0.00 & 0.49 & Non-stationary \\
\hline \multicolumn{11}{|c|}{ First Differences } \\
\hline Tests & \multicolumn{3}{|c|}{ LLC } & \multicolumn{3}{|c|}{ ADF } & \multicolumn{3}{|c|}{$\mathbf{P P}$} & \multirow[b]{2}{*}{ Decision } \\
\hline Variables & Intercept & $\begin{array}{l}\text { Trend \& } \\
\text { intercept }\end{array}$ & None & Intercept & $\begin{array}{l}\text { Trend \& } \\
\text { intercept }\end{array}$ & None & Intercept & $\begin{array}{l}\text { Trend \& } \\
\text { intercept }\end{array}$ & None & \\
\hline GDP & 0.00 & 0.00 & 0.00 & 0.00 & 0.00 & 0.00 & 0.00 & 0.00 & 0.00 & Stationary \\
\hline GFCF & 0.00 & 0.00 & 0.00 & 0.00 & 0.00 & 0.00 & 0.00 & 0.00 & 0.00 & Stationary \\
\hline GGFC & 0.00 & 0.00 & 0.00 & 0.00 & 0.00 & 0.00 & 0.00 & 0.00 & 0.00 & Stationary \\
\hline TNRR & 0.00 & 0.00 & 0.00 & 0.00 & 0.00 & 0.00 & 0.00 & 0.00 & 0.00 & Stationary \\
\hline
\end{tabular}

*Indicates the rejection of Null Hypothesis, meaning that the variables are stationary.

Table 2. Unit Root Test Results 
The null hypothesis of this test is "There is unit root" and according to the prob-value of intercept, Trend \& intercept and None tests in Table-2, we accepted the null hypothesis indicating that there is unit root inside our data. This means also that our data are not stationary in Level. We performed the test by taking the first difference and we procced to reject the null hypothesis because all the probability values are less than $5 \%$, meaning that the variables are stationary in first difference.

\subsection{Panel Regression Model Estimation}

The panel regression model was estimated with Fixed/Random effects model and the model estimation is given in Table-3. However, in order to choose the appropriate model we performed the Hausman test which the Null Hypothesis is "Random Effects".

According to Table-3, Capital Formation and the constant are significant in 5\% level. Natural resources rents and government final consumption expenditure are not significant. The result of Hausman test indicates the rejection of null hypothesis in 5\% level, meaning that we can choose the fixed effects model at $5 \%$ significance level, because also the R-squared is very high.

\begin{tabular}{|c|c|c|c|c|c|c|c|c|}
\hline \multirow{2}{*}{ Variables } & \multicolumn{4}{|c|}{ Fixed Effect Model } & \multicolumn{4}{|c|}{ Random Effect Model } \\
\hline & Coefficients & Std.Error & $t$-Statistic & Prob. & Coefficients & Std.Error & $t$-Statistic & Prob. \\
\hline TNRR & -3.10 & 2.50 & -1.24 & 0.22 & -2.98 & 2.50 & -1.19 & 0.2326 \\
\hline GGFC & -5.48 & 4.58 & -1.20 & 0.23 & -4.935177 & 4.58 & -1.078 & 0.2810 \\
\hline GFCF & 9.077 & 2.30 & 3.94 & $0.0001 *$ & 9.261592 & 2.30 & 4.02 & 0.0001 \\
\hline $\mathrm{C}$ & 1570.16 & 80.25 & 19.57 & $0.0000 *$ & 1557.460 & 339.039 & 4.59 & 0.0000 \\
\hline R-Squared & \multicolumn{4}{|c|}{$95.7 \%$} & \multicolumn{4}{|c|}{$1.6 \%$} \\
\hline \multicolumn{2}{|c|}{ Hausman Test } & & & & & & & $0.7 \%$ \\
\hline
\end{tabular}

\section{Table 3. Fixed/Random Effects Model Estimation}

The equation of fixed effects is given as follow:

$$
G D P=-3.1 T N R R+-5.48 G G F C+9.08 G F C F+1570.16
$$

According to this equation, one unit increase in GDP leads to 3.1 units decrease in Natural resources rents and 5.48 units decrease in government final consumption expenditure. In other words, there is negative and significant relationship between natural resources rents, government final consumption expenditure and economic growth. However, capital formation is affecting the economic growth positively.

\subsection{Causality Test}

Table-4 shows the results of Pairwise Panel Causality test adopted by Dumitrescu-Hurlin (2012).

\begin{tabular}{|l|r|r|r|}
\hline Null Hypothesis: & W-Stat. & Zbar-Stat. & Prob. \\
\hline DTNRR does not homogeneously cause DGDP & 4.49875 & 2.07091 & $0.0384 *$ \\
\hline DGDP does not homogeneously cause DTNRR & 4.55766 & 2.17949 & $0.0293 *$ \\
\hline DGGFC does not homogeneously cause DGDP & 4.15332 & 1.43433 & 0.1515 \\
\hline DGDP does not homogeneously cause DGGFC & 5.99561 & 4.82942 & $1 . E-06$ \\
\hline DGFCF does not homogeneously cause DGDP & 3.93987 & 1.04097 & 0.2979 \\
\hline DGDP does not homogeneously cause DGFCF & 3.33164 & -0.07990 & 0.9363 \\
\hline DGGFC does not homogeneously cause DTNRR & 4.72671 & 2.49102 & $0.0127 *$ \\
\hline DTNRR does not homogeneously cause DGGFC & 3.12751 & -0.45609 & 0.6483 \\
\hline DGFCF does not homogeneously cause DTNRR & 3.49214 & 0.21588 & 0.8291 \\
\hline DTNRR does not homogeneously cause DGFCF & 5.46645 & 3.85425 & $0.0001 *$ \\
\hline DGFCF does not homogeneously cause DGGFC & 3.14491 & -0.42402 & 0.6716 \\
\hline DGGFC does not homogeneously cause DGFCF & 3.20443 & -0.31434 & 0.7533 \\
\hline${ }^{*}$ Rejection of Null Hypothesis, meaning that causality link exists between variables. & & \\
\hline
\end{tabular}

Table-4: Pairwise Dumitrescu Hurlin Panel Causality Tests (Lags: 3)

According to Table-4, there is bidirectional causality relationship between Natural resources rents and economic growth. Causality test results show also that there is unidirectional causality link from government final consumption expenditure to Natural resources revenue and from Natural resources revenue to capital formation.

\section{Conclusion}

In this study we investigated the relationship between Natural resources rents, Fiscal policy and economic growth with panel data analysis by using data of 35 selected Sub-Saharan African countries covering the periods of 1986-2014. In this context we performed the unit root tests (LLC, ADF and PP) in order to examine whether 
the variables are stationary or not. The unit root test results indicate that all the variables are stationary in first difference. So now we are able to estimate the panel least squares equation by using Fixed/Random effect model and we also performed the Pairwise Panel Causality test.

The empirical results indicate that there is insignificant negative effect of natural resources revenue and bad fiscal policy on the economic growth. However, there is significant positive effect of capital formation on economic growth. We also found a bidirectional causality relationship between Natural resources rents and economic growth. There is also unidirectional causality link from government final consumption expenditure to Natural resources revenue and from Natural resources revenue to capital formation. In other words, government final consumption expenditure causes natural resource revenues which in turn cause capital formation then economic growth and vice versa. These empirical results mean that Sub-Saharan African countries apply bad fiscal policy to improve the natural resource sector. They earn a lot of money from this sector which they use in order to form capital in the natural resources sector, which brings them to focus only on natural resources rents. This situation of natural resources dependence and the bad fiscal policy warm the economy of Sub-Saharan Africa. However, if they improve their fiscal policy and form capital in other sectors, they will see their economies grow. This study suggests that countries of Sub-Saharan Africa must apply improved fiscal policy in order to add tax revenue to their total revenue; and they must also use the natural resources revenue in order to invest in other sectors such as education, manufacturing and Agriculture.

\section{References}

- Al Jazeera. (2016, October 28). Mapping Africa's natural resources. Retrieved June 25, 2017, from Al Jazeera: http://www.aljazeera.com/indepth/interactive/2016/10/mapping-africa-natural-resources161020075811145.html

- Asiedu, E. (2006). "Foreign Direct Investment in Africa: The Role of Natural Resources, Market Size, Government Policy", Institutions and Political Instability. World Economy, 29(1), 63-77.

- Awolusi, O. D. (2016). Mining Sector and Economic Growth in Southern African Economies: A Panel Data Analysis. University of KwaZulu-Natal. Durban: Trade \& Industrial Policy Strategies (TIPS).

- Badeeb, R., Lean, H. H., \& Clark, J. (2016). The Evolution of the Natural Resource Curse Thesis: A Critical Literature Survey. Department of Economics and Finance. Christchurch: University of Canterbury.

- Choi, I. (2001). "Unit root tests for panel data". Journal of International Money and Finance, 20(2), 249-272.

- Dumitrescu, E.-I., \& Hurlin, C. (2012). Testing for Granger Non-causality in Heterogeneous Panels. Orleans: HAL.

- EViews. (2017, June 12). Panel Cointegration Estimation. Retrieved from E-views: http://www.eviews.com/help/helpintro.html\#page/content\%2FpancointPanel_Cointegration_Estimation.html\%23

- EViews. (2017, June 26). Panel Causality Testing. Retrieved June 26, 2017, from E-views: http://www.eviews.com/help/helpintro.html\#page/content\%2Fpanelstats-Panel_Causality_Testing.html

- Guzman, T. A. (2014, May 04). John Kerry says Africa has "Natural Resources", Therefore the US is a "Natural Partner". Retrieved June 29, 2017, from GlobalResearch.ca: http://www.globalresearch.ca/ussecretary-of-state-john-kerry-says-africa-has-natural-resources-therefore-the-us-is-a-naturalpartner $/ 5380395$

- Gylfason, T., \& Zoega, G. (2002). Inequality and Economic Growth: Do Natural Resources Matter? CESifo Working Paper No. 712, Center for Economic Studies.

- Hayat, A. (2014). FDI and Economic Growth: The Role of Natural Resources. Charles University. Prague: Institute of Economics Studies.

- Janda, K., \& Quarshie, G. (2017). "Modelling Natural Resources, Oil and Economic Growth in Africa". Munich Personal RePEc Archive.

- Karimu, A., Adu, G., Marbuah, G., Mensah, J. T., \& Amuakwa-Mensah, F. (2016). "Natural Resource Revenues and Public Investment in Resource-rich Economies in Sub-Saharan Africa". WIDER. UNUWIDER.

- Levin, A., Lin, C.-F., \& Chu, C.-S. J. (2002). "Unit root tests in panel data: asymptotic and finite-sample properties". Journal of Econometrics, 1-24.

- Maddala, G. S., \& Wu, S. (1999). "A Comparative Study of Unit Root Tests with Panel Data and a New Simple Test". Oxford Bulletin of Economics and Statistics, 631-52.

- Panel Causality Testing. (2017, June 12). Retrieved from E-views: http://www.eviews.com/help/helpintro.html\#page/content\%2Fpanelstats-Panel_Causality_Testing.html

- Sachs, J. D., \& Warner, A. M. (1995). "Natural Resource Abundance and Economic Growth". NBER. 
- Thorborg, N., \& Blomqvist, M. (2015). "Natural Resource Watch: Report on: Sub-Saharan Afric"a July 2015. Copenhagen: Oxfam IBIS.

- Ugwuanyi, U. B., \& Ugwunta, O. D. (2017). "Fiscal Policy and Economic Growth: An Examination of Selected Countries in Sub-Saharan Africa. International Journal of Academic Research in Accounting", Finance and Management Sciences, 7(1), 117-130.

- World Bank. (2017, june 12). World Development Indicators Database. Retrieved from The World Bank: http://databank.worldbank.org/data/reports.aspx?source=world-development-indicators\# 